\title{
DESAIN SISTEM INTELEJENSIA BISNIS PADA RANTAI PASOK PRODUK JAMU BERBASIS PENTAHO BUSINESS INTELLIGENCE
}

\author{
Aster Aryati, Dian Anwar \\ E-mail: aster@gmail.com \\ Program studi Manajemen Logistik Industri Elektronika \\ Politeknik APP Jakarta
}

\begin{abstract}
This paper designs business intelligence system for supply chain of herbal products in Indonesia. System design is done with system entity approach to obtain system attributes, conceptual system design using Businees Process Modeling Notation (BPMN) 2.0 and unified modeling language (UML) and finally integrated with pentaho business intelligence suite suite including integration and business analytics data. The result of business intelligence system design is able to transform raw data into information and mengintrpertasikannya in the form of a visual supply chain herbal products for the purposes of identification, development and create new business strategy opportunities.
\end{abstract}

Keywords: system analysis, system design, keyword business intelligence systemEnglish

\begin{abstract}
Abstrak
Paper ini mendesain sistem intelejensia bisnis untuk rantai pasok produk jamu di Indonesia. Desain sistem dilakukan dengan pendekatan entitas sistem untuk mendapatkan atribut-atribut sistem, desain konspetual sistem menggunakan Businees Process Modelling Notation (BPMN) 2.0 dan unified modelling language (UML) dan terakhir diintegrasikan dengan kumpulan aplikasi intelejensia bisnis pentaho meliputi data integration and business analytics. Hasil desain sistem intelejensia bisnis mampu mentransformasi data mentah menjadi informasi dan mengintrpertasikannya dalam bentuk visual pada rantai pasok produk jamu untuk kepentingan identifikasi, pengembangan dan membuat kesempatan strategi bisnis baru.
\end{abstract}

Kata Kunci : analisis sistem, desain sistem, sistem intelejensia bisnis kata kunci 


\section{PENDAHULUAN}

Jamu adalah salah satu jenis herbal asli Indonesia yang secara empiris telah dibuktikan khasiatnya yang dibuat dari bahan-bahan alami berupa bagian dari tumbuhan seperti rimpang (akar-akaran), daun-daunan, kulit batang, dan buah. Bahan lainnya dari telur, tubuh hewan, seperti empedu kambing, empedu ular, atau tangkur buaya khas Indonesia (Afdal dan Welsch 1988)

Herbal khas Indonesia ini telah banyak dikembangkan menjadi bentuk bisnis baik itu dalam bentuk bisnis usaha kecil menangah, maupun produksi besar skala pabrik. Hal ini dikarenakan bisnisjamu tradisional cukup mudah dijalankan dan bisa menjadi salah satu cara untuk mendapatkan penghasilan. Rasa nikmat dan segar yang diciptakan dari jamu ini masih tetap diminati oleh masyarakat, dengan hal tersebut maka peluang pasar untuk bisnis ini menjadi semakin menjanjikan. (Pribadi 2015)

Walaupun jamu adalah minuman tradisional namun minuman ini masih memiliki penikmat yang banyak atau target pasar yang luas di Indonesia. Dengan terangkatnya aneka minuman seperti jamu tradisional ini membuat para pelaku usaha jamu memiliki dampak yang bagus. Telah banyak produk jamu yang sudah masuk ke aneka took dan aneka supermarket dengan kemasan modern yang lebih praktis. Hal ini membuat peluang dari jamu tradisional semakin menggiurkan, untuk menjalankan usaha jamu ini pun juga tidak membutuhkan modal yang besar. Dengan memanfaatkan peralatan yang ada di dapur rumah maka membuat jamu pun bisa dijalankan, selain itu memilih lokasi berjualan yang tepat seperti di pinggir-pinggir jalan atau pun bisa juga dengan berjualan di depan rumah.
Beberapa masalah yang sering dihadapi oleh para pelaku usaha jamu adalah adanya persediaan bahan baku jamu atau rempahrempah yang relative ti dak stabil. Persediaan bahan baku jamu ini dipengaruhi oleh cuaca, sehingga bila dipasarkan persediaan semakin sedikit maka harga jualnya akan naik. Oleh karena itu para penjual jamu harus bisa bekerja sama dengan petani rempah supaya persediaan bahan pembuat jam uterus terjaga dan bisa memperoleh harga yang terjangkau.

Kerjasama ini membentuk rantai pasok jamu dengan aliran bahan baku remah-rempah, pengolahan dan penjualan hasil pengolahan jamu kepada konsumen. Rantai pasok dengan aliran uang, informasi dan teknologi yang umumnya masih sederhana ini menimbulkan banyak masalah seperti pembagian keuntungan berdasarkan resiko pengolahan yang dihadapi, banyaknya yang belum terstandarisasi, aliran informasi yang relative lebih lambat sehingga memerlukan pengembangan intelejensia yang baik agar rantai pasok bisnis jamu mampu mentransformasi data mentah menjadi informasi dan mengintrpertasikannya dalam bentuk visual pada rantai pasok produk jamu untuk kepentingan identifikasi, pengembangan dan membuat kesempatan strategi bisnis baru produksi jamu.

Paper ini mengembangkan sistem intelejensia bisnis pada rantai pasok jamu untuk menampilkan visualisasi arus data dan informasi secara simulasi menggunakan pendekatan sistem intelejensia bisnis. Paper terbagi atas 2 bagian, bagian pertama menjelaskan mengenai metodologi berupa tahapan kerja penelitian analisis dan desain sistem hingga tahapan implementasi sistem intelejensia bisnis menggunakan pentaho. Tahap kedua paper ini menampilkan hasil-hasil simulasi arus data dan informasi menggunakan pentaho dan membahas kemungkinan strategistrategi pengembangan bisnis pada sistem 
rantai pasok jamu, dan diakhiri dengan kesimpulan.

\section{METODOLOGI}

Paper ini dibagi atas dua kerangka kerja besar. Tahap pertama adalah analisis dan desain sistem menggunakan pendekatan BPMN 2.0 dan UML. Tahap ini akan menghasilkan konseptual sistem intelejensia bisnis. Tahap kedua adalah kerangka kerja implementasi sistem intelejensia bisnis berbasis perangkat lunak Pentaho yang terdiri dari data integration dan business analytics. Secara lebih jelas dideskripsikan pada gambar 1

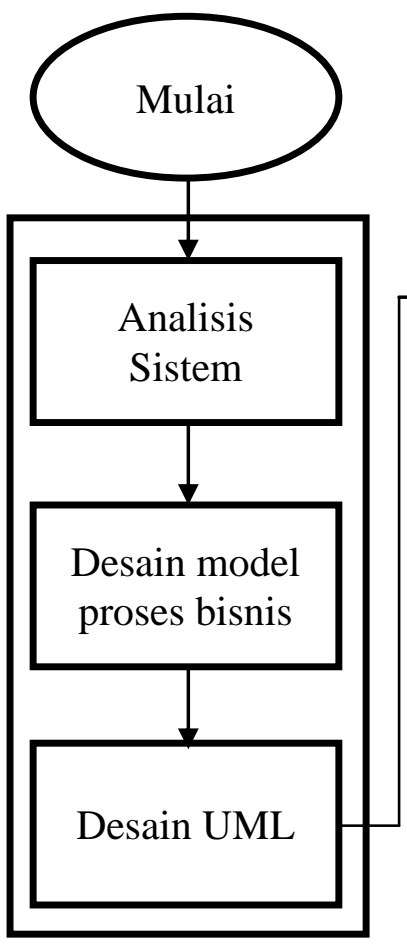

Implemantasi sistem intelejensia bisnis dengan

Pentaho

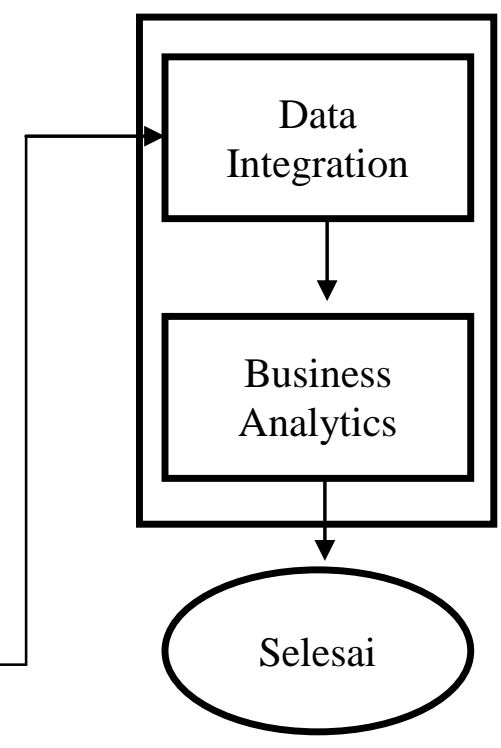

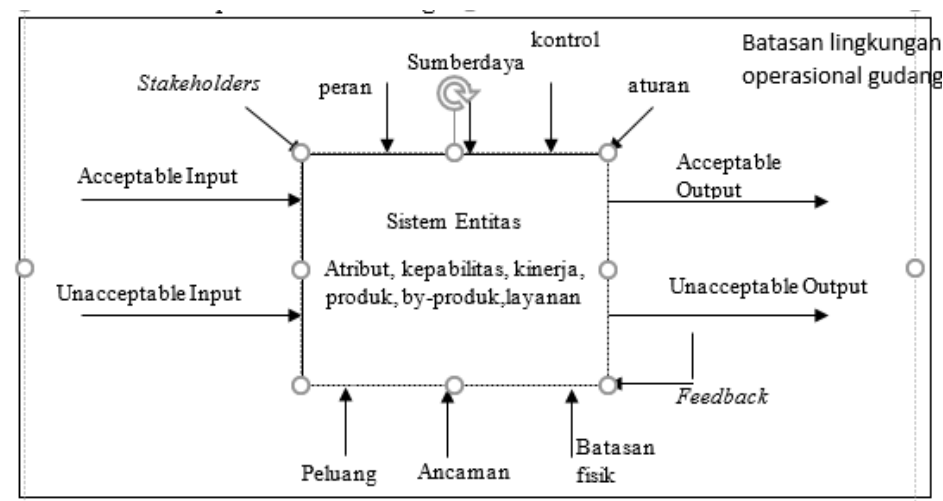

Gambar 1. Kerangka kerja desain sistem intelejensia bisnis rantai pasok jamu

\section{a. Analisis Kebutuhan Sistem}

Analisis kebutuhan dianalisis menggunakan pendekatan entitas sistem yang diusulkan digambarkan pada gambar 2 .

Analisis dan

Desain Sistem 


\section{b. Desain Model Proses Bisnis}

Setelah analisis kebutuhan dilakukan, tahap selanjutnya adalah mendesain model konseptual untuk mengetahui perilaku dari sistem distribusi biodiesel berbasis minyak sawit di Indonesia. Paper ini menggunakan diagram konseptual BPMN 2.0 sebagai represeantasi konseptual desain sistem. BPMN 2.0 adalah notasi grafis terstandarisasi yang digunakan untuk mempermudah memahami tidak hanya pelaku pada suatu sistem namun juga analisis dan pengembangan teknis yang memiliki peran tertentu dalam mengkonfigurasi dan mengawasi implementasi suatu sistem. Gambar 3 adalah notasi yang digunakan pada diagram BPMN2.0 (Power Designer 2015).

\section{c. Desain UML}

UML adalah sekumpulan alat yang digunakan untuk melakukan abstraksi terhadap sebuah sistem atau perangkat lunak berbasis objek. Unified Modeling Language (UML) adalah bahasa spesifikasi standar untuk mendokumentasikan, menspesifikasikan, dan membangun sistem perangkat lunak. UML adalah metodologi untuk mengembangkan sistem OOP dan sekelompok perangkat

tool untuk mendukung pengembangan sistem tersebut. UML memiliki 10 bentuk diagram, paper ini menggunakan use case diagram untuk perspektif bisnis rantai pasok jamu pada perspektif pengguna sistem intelejensia bisnis, dan class diagram yang dapat dikonversi dalam bentuk physical data diagram yang akan digunakan untuk pengembangan manajemen basis data pada data integration Pentaho. Gambar 4 adalah notasi pada use case dan class diagram.

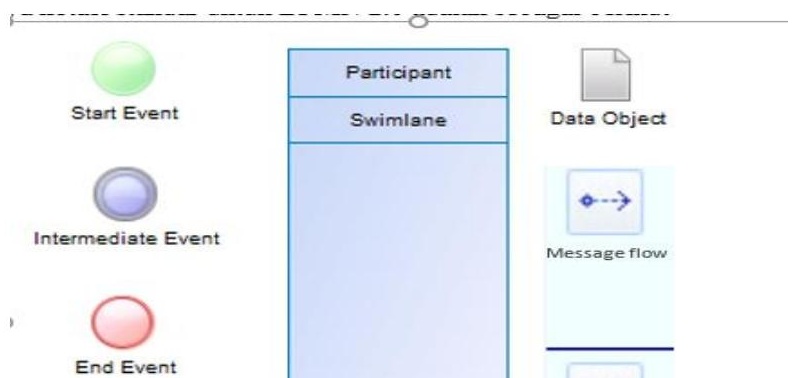

Gambar 3. Notasi pada BPMN 2.0

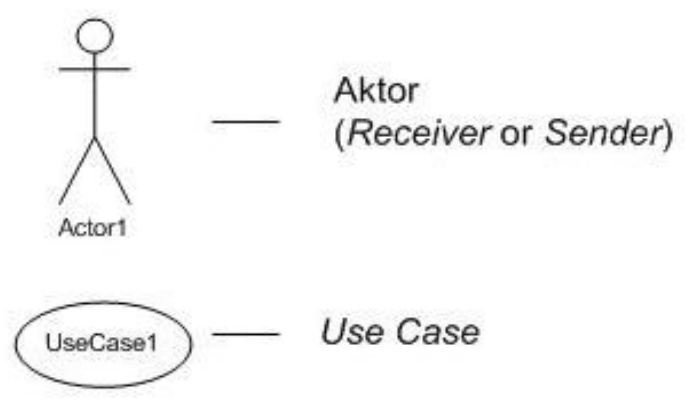

(a)

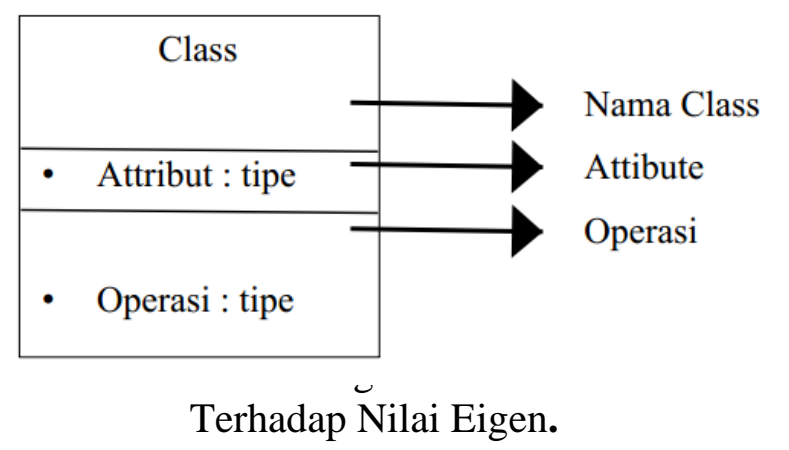

(b)

Gambar 4. (a) notasi pada use case diagram dan (b) notasi pada class diagram

\section{d. Data integration}

Pentaho Data Integration (PDI) adalah sebuah ETL tool open source yang populer. Selain versi enterprise, ada versi community yang bisa kita gunakan secara cuma-cuma. PDI dapat dijalankan sebagai aplikasi standalone atau sebagai aplilasi client-server, dimana development dilakukan di komputer dan eksekusi dijalankan di server. (Bouman dan Van Doungen 2009) 


\section{e. Business Analytics}

Pentaho business analytics adalah salah satu perangkat pengembangan sistem intelejensia bisnis Pentaho dengan karakteristik yang sederhana dan interkatif untuk mmbantu mengambil keputusan dalam rangka meningkatkan kinerja suatu bisnis. Perangkat ini terdiri dari fitur-fitur laporan dasar untuk kepentingan pemodelan prediksi, menganalisis dan memvisualisasi data dalam bentuk dimensidimensi data yang banyak. (Caster et al 2010).

\section{Hasil dan Pembahasan}

\section{a. Analisis Kebutuhan}

Berdasarkan hasil analisis sistem yang dilakukan input pada sistem intelejensia rantai pasok jamu adalah inputan bahan baku yang terdiri dari jumlah dan mutu, permintaan konsumen, kualitas produk, finansial, logistik serta inputan-inputan pada proses produksi. Proses pada sistem intelejensia meliputi proses visualisasi data rantai pasok, proses knowledge discovery seperti pola permintaan, klaster dan klasifikasi pemasok, klasifikasi produk berdasarkan fungsionalnya. Aturan-aturan meliputi standar kualitas dan sanitasi, aturan jumlah pasokan dan aturan-aturan berupa kontrak antar pelaku rantai pasok. Output yang dihasilkan pada setiap tingkatan rantai pasok seperti total produk yang dihasilkan produsen jamu, total keuntungan, total kualitas dan kuantitas jamu, dan kinerja rantai pasok. Ancaman berupa jumlah bahan baku yang mudah rusak dan kualitas produk olahan jamu. Aktor dan peran pada rantai pasok ini meliputi petani tumbuhan herbal sebagai pemasok, pedagang pengumpul desa sebagai pemasok lanjutan, produsen jamu usaha kecil menengah, produsen jamu skala pabrikan/besar sebagai aktor pengolah bahan herbal menjadi produk jamu dan distributor serta penjual jamu sebagai penyalur produk jamu olahan kepada konsumen. Untuk menghadapi ancaman, kontrol yang dilakukan pada sistem intelejensia bisnis ini adalah data cleaning pada tahap data integration dan kontrol sistem business analytics. Secara skema rantai pasok jamu di deskripsikan pada gambar 5. Hasil analisis sistem ini akan menjadi dasar dalam mengambangkan diagram konseptual (model proses bisnis dan UML) untuk implementasi sistem intelejensia bisnis pada kerangka kerja Pentaho.

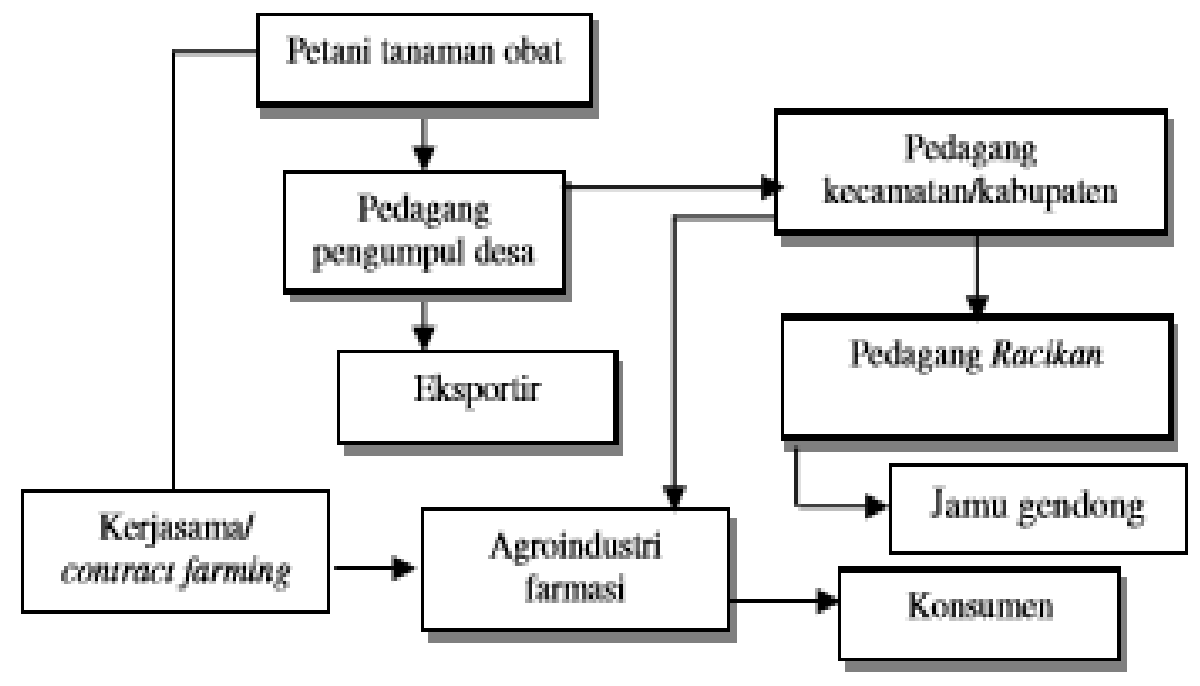


Gambar 5. Skema aktor rantai pasok jamu

\section{b. Desain model proses bisnis}

Merujuk pada hasil analisis sistem, tahap ini menghasilkan konseptual model proses bisnis sistem intelejensia rantai pasok jamu dengan proses utama terbagi atas 3 yaitu akuisis data dari aktor-aktor rantai pasok jamu, proses visualisasi data dan analisis keputusan berdasarkan hasil interpretasi visualisasi data. Tahapan top level pada model proses bisnis digambarkan pada gambar 6

\section{c. Desain UML}

Desain ini digunakan sebagai dasar-dasar dalam mendesain proses-proses bisnis sistem intelejensia rantai pasok jamu. Diagram yang digunakan pada paper ini adalah Use Case untuk mengetahui interkasi antar actor dan Class diagram untuk mengetahui proses dan data-data yang diperlukan dalam implementasi sistem intelejensia bisnis. Beberapa bagian diagram use case pada gambar 7 memperlihatkan aktor-aktor rantai pasok yaitu petani, pemasok, produsen jamu dan distributor-reseller dengan interkasi masingmasingnya dalam menjalankan bisnis jamu dan kontribusinya pada sistem intelejensia bisnis.

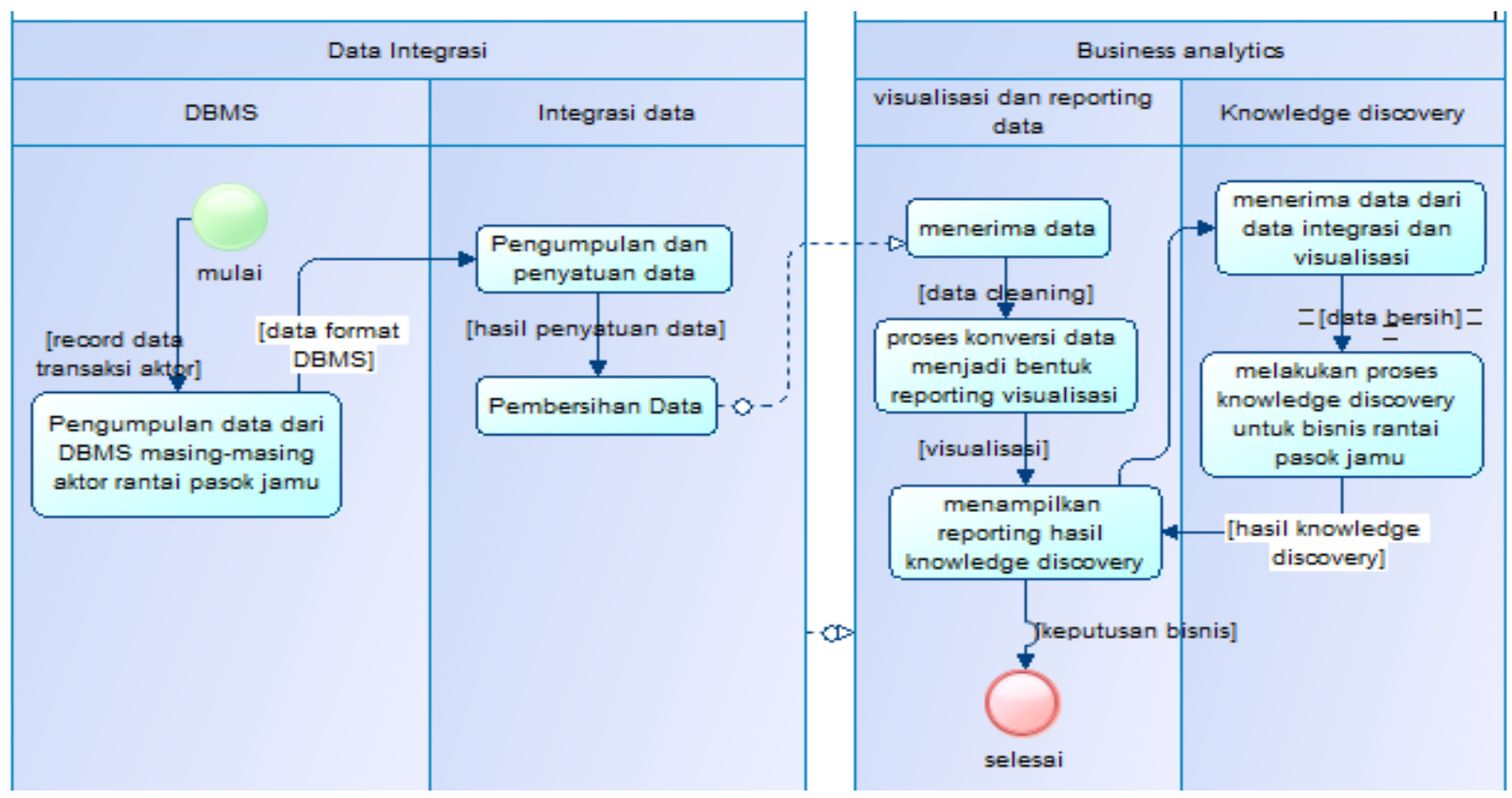

Gambar 6. Model proses bisnis top level sistem intelejensia bisnis rantai pasok jamu 

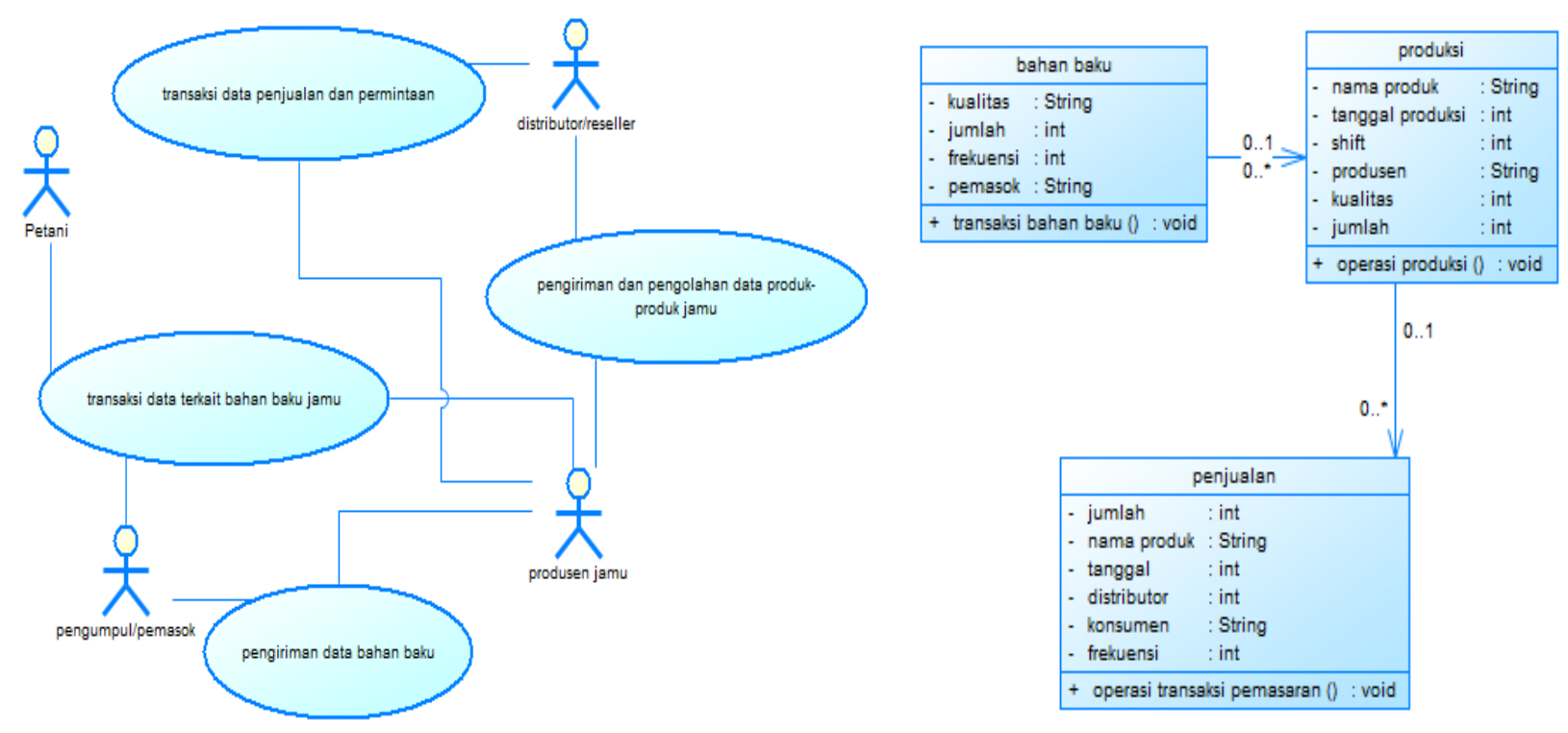

Gambar 7. Beberapa bagian Use Case dan Class Diagram sistem intelejensia bisnis jamu

\section{d. Data Integration}

Data integration yang digunakan pada perangkat kerja

bersih untuk Pentaho Business Analytics.

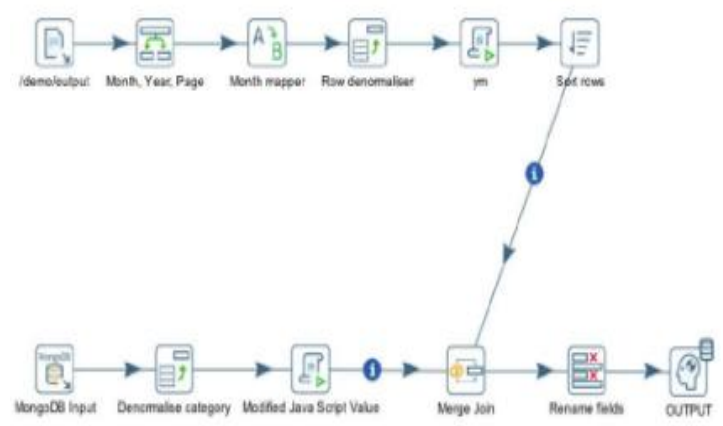

Gambar 8. Integrasi data menggunakan Pentaho data Integration

\section{e. Business Analytics}

Business analytics menghasilkan pelaporan dan visualisasi dari data yang sudah dibersihkan pada tahapan data integration. Gambar 9 adalah contoh preview data
Pentaho meliputi proses integrase data dari banyak DBMS masing-masing aktor rantai pasok jamu dan cleaning data (Gambar 8). Hasilnya adalah data penjualan yang akan divisualisasikan dalam bentuk pelaporan untuk kepentingan analisis dan knowledge discovery. Setelah itu dilakukan penampilan pelaporan. Laporan dalam bentuk grafik.

Hasil report pada gambar 10 memperlihatkan visualisasi jumlah produk prospektif yang banyak dipesan oleh konsumen sehingga membutuhkan bahan baku yang lebih banyak dan kontinu dibandingkan produk lainnya, Adapun produk dengan jumlah pemesanan terkecil dapat dikurangi intensitas dan frekuensi pemasokan bahan bakunya. Contoh pada penjualan ini dapat dilanjutkan./sebagai dasar pada knowledge discovery menggunakan pendekatan-pendekatan data mining untuk memperoleh keputusan yang tepat dalam pengembangan bisnis rantai pasok agroindustri jamu. 


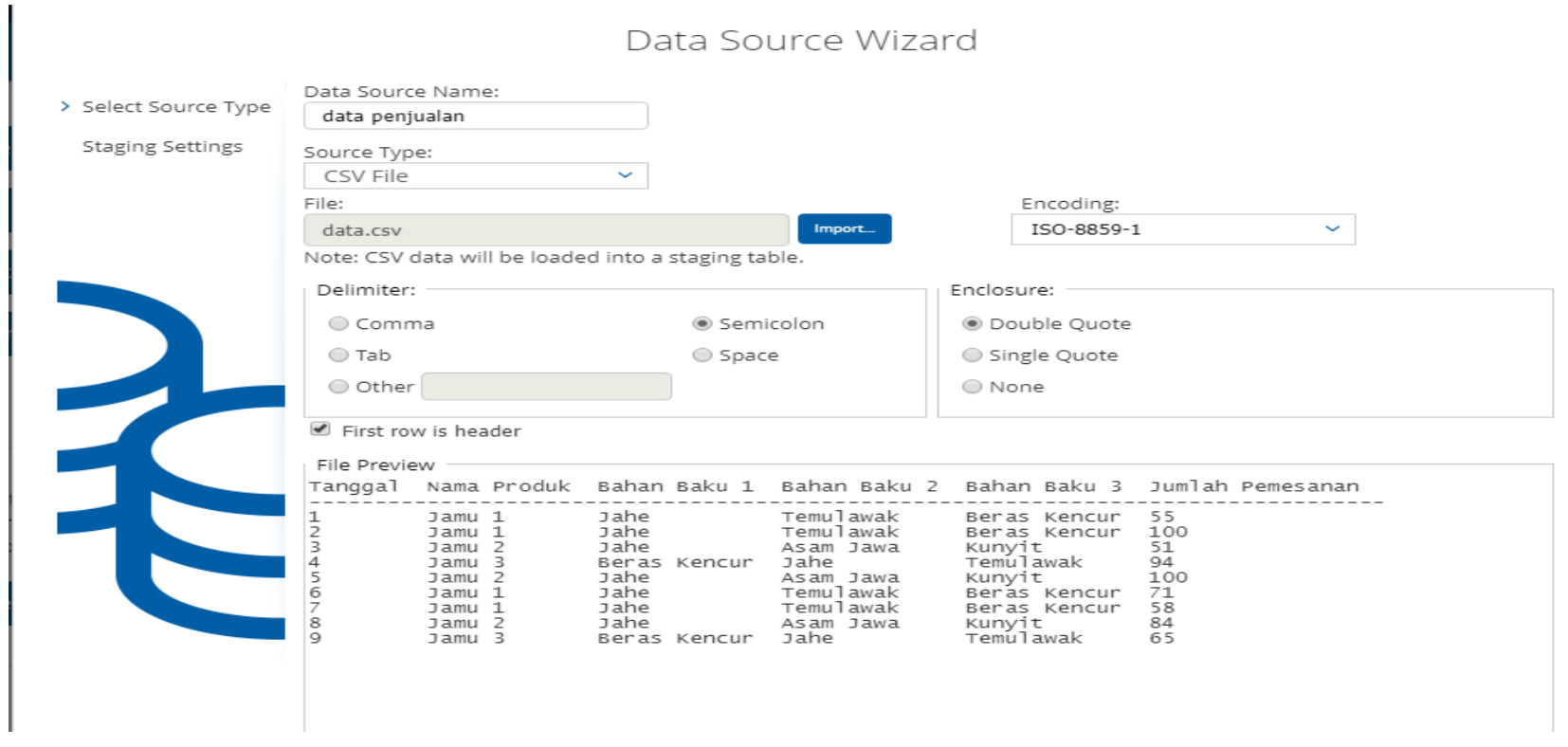

Gambar 9. Contoh import data penjualan untuk tahapan business analytics menggunakan pentaho 

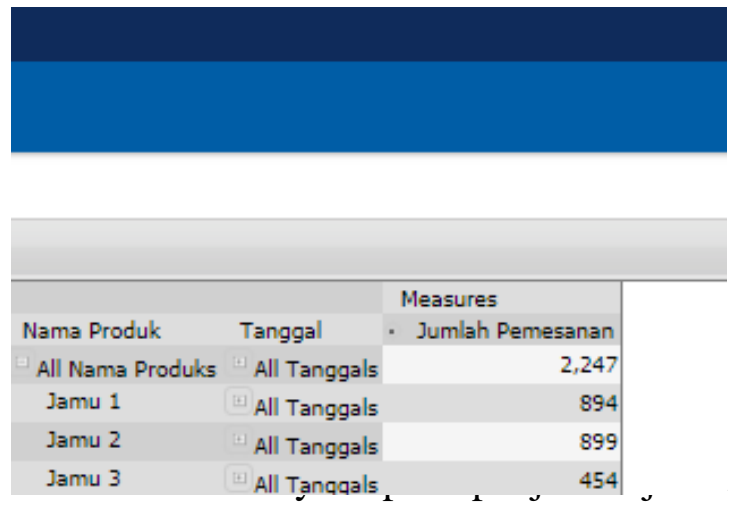

\section{Kesimpulan}

Paper ini mendesain sistem intelejensia bisnis untuk rantai pasok produk jamu di Indonesia. Desain sistem dilakukan dengan pendekatan entitas sistem untuk mendapatkan atribut-atribut sistem, desain konspetual sistem menggunakan Businees Process Modelling Notation (BPMN) 2.0 dan unified modelling language (UML) dan terakhir diintegrasikan dengan kumpulan aplikasi intelejensia bisnis pentaho meliputi data integration and business analytics. Hasil desain sistem intelejensia bisnis mampu mentransformasi data mentah menjadi informasi dan mengintrpertasikannya dalam bentuk visual pada rantai pasok produk jamu untuk kepentingan identifikasi, pengembangan dan membuat kesempatan strategi bisnis baru. Contoh pada data penjualan yang ditampilkan pada bagian business analytics memperlihatkan jumlah produk yang banyak dibeli oleh konsumen dan sedikit dibeli konsumen. Produk yang banyak dibeli konsumen membutuhkan bahan baku yang lebih banyak dan kontinu untuk memenuhi permintaan. Penelitian selanjutnya dapat diarahkan pada knowledge discovery pada rantai pasok seperti klasifikasi dan klaster bahan baku serta pemasok, penjadwalan, trend permintaan, hingga pembagian revenue berdasarkan resiko yang ditanggung oleh masing-masing aktor rantai pasok jamur.

\section{Daftar Pustaka}

Afdhal, A. F., \& Welsch, R. L. (1988). The rise of the modern jamu industry in Indonesia: a preliminary overview. The context of medicines in developing countries: studies in pharmaceutical anthropology, 149172.

Bouman, R., \& Van Dongen, J. (2009). Pentaho solutions: business intelligence and data warehousing with Pentaho and MySQL. Wiley Publishing.

Casters, M., Bouman, R., \& Van Dongen, J. (2010). Pentaho Kettle solutions: building open source ETL solutions with Pentaho Data Integration. John Wiley \& Sons.

PowerDesigner, S. A. P. (2015). Sybase PowerDesigner 16.5, 2013.

Pribadi, E. R. (2015). Pasokan dan permintaan tanaman obat Indonesia serta arah penelitian dan pengembangannya. Perspektif, 8(1), 52-64.

Wasson, C. S. (2015). System engineering analysis, design, and development: Concepts, principles, and practices. John Wiley \& Sons. 